\title{
CLUSTER APPROACH TO INCREASING THE PRESTIGE OF PUBLIC SERVICE
}

Nazar Podolchak, Doctors of Economics, Professors, Head of Department of Administrative and Financial Management, Lviv Polytechnic National University, Lviv, Ukraine.

Veronika Karkovska, $\mathrm{PhD}$ of economic sciences, associate professorDepartment of Administrative and Financial Management, Lviv Polytechnic National University, Lviv, Ukraine.

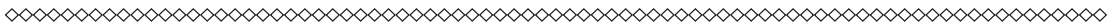

Updating the prestige of the public service is a prerequisite for successful European integration and good and efficient public administration that meets the requirements of modern times and European standards and principles of good governance. The aim of the article is to study the prestige of public service through cluster analysis. The article considers the directions of increasing the prestige of public service and highlights the main advantages. The research is based on the analysis of indicators that directly affect the formation of the prestige of the public service of Ukraine and leading countries. Also, to take into account the prestige, international indices were selected, which are the result of the effectiveness of public administration and the macroeconomic environment, as they reflect the opportunities and freedom of activity. With the help of cluster analysis, the classification of indicators that characterize the level of prestige of the civil service in different countries is carried out. As a result, the formation of clusters of prestige of the civil service in different countries of the world is considered and practical recommendations for its increase are presented. It is established that the prestige of the public service is of paramount functional importance, as it is civil servants who are the real leaders of publicity ideas in practice. 
Cluster approach to increasing the prestige of public service

The article concludes that the prestige of public service largely depends not only on the availability of highly qualified staff, but also on efficiency, but also on the trust, respect of the population, on how the laws and regulations of public authorities will be perceived in public opinion. The prestige of public service is a key indicator of the efficiency and strength of the state in the international environment. It also directly affects the state's ability to provide services to the population, promote competition and growth.

Keywords: public service prestige, cluster analysis, public service prestige indicators, country clustering, level of public service prestige.

Introduction. Throughout the development of society, the concept of public service has traditionally been regarded as a special type of public activity, carried out on a professional basis by employees of public bodies for the purpose of performing functions and tasks. Public servants differed from other citizens in their authority and therefore were always respected. This is evidenced by the reform of public administration, which is one of the priority reforms of the sustainable development "Ukraine 2020 " to build a transparent system of public administration [22]. The professionalism of the Public Service Institute, ensuring its efficiency, modernizing the public service and managing human resources are one of the key areas of ensuring the prestige of the public service.

Updating the prestige of the public service is a prerequisite for successful European integration and good and efficient public administration that meets the requirements of modern times and European standards and principles of good governance. The key to improving the prestige of the public service is the following benefits from this process (picture 1).

The positive impact of enhancing the prestige of the public service should be considered in more detail:

1. Possibility of attracting the best workforce. An important role in improving the organization of the public service is played by the process of professional training and selection of candidates for the competition for vacant positions of public service. This is one way of ensuring the 


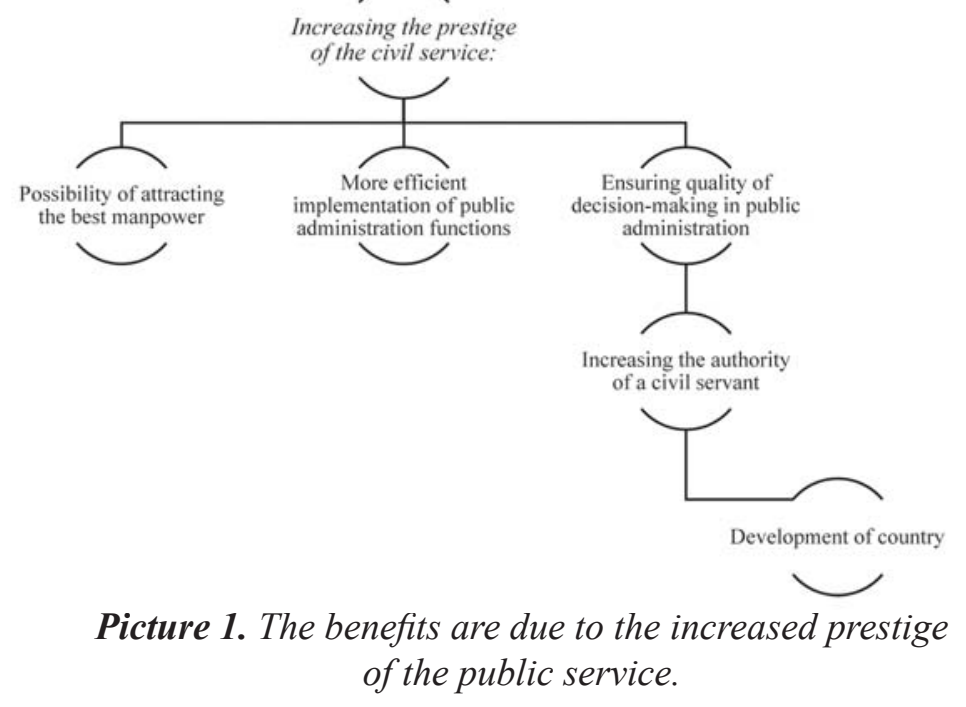

prestige of the public service. In the context of market transformation processes, the best manpower is able to act effectively, show autonomy and initiative; be able to take risks; be able to respond to environmental changes in a timely and correct manner by making sound management decisions; think strategically; quickly determine the effectiveness of innovations; quickly restructure the work of the state structure, as well as be sociable and able to regulate interpersonal relationships.

2. More efficient implementation of public administration functions. Optimizing the functions of government institutions, ensuring the effective division of powers and areas of responsibility between them, identifying and enhancing the overall administrative and administrative capacity of the state apparatus on the basis of good governance principles and the best experience of EU Member States, transforming it into an effective tool for the continuous and sustainable development of Ukraine.

3 . Ensuring the quality of decision-making in public administration. The key elements of the prestige of the public service at the present stage are improving the quality of the public service and the service in local self-government bodies. In the process of establishing a new model 498 Isue DOI: 10.34132/pard 
Cluster approach to increasing the prestige of public service

of government, the role of the public servant is changing. Continuous training of public servants is essential, which promotes the prestige of the public service.

4. Increasing the authority of a public servant. According to Article 1 of the Law of Ukraine "On Public Service", the public service in Ukraine is the professional activity of persons holding positions in state bodies and their apparatus in the practical fulfillment of the tasks and functions of the state and receive wages at the expense of public funds. Therefore, the task of the modern public servant is to create a system of public administration that will ensure the further active development of Ukraine as a legal, publicized European state with a high standard of living, social stability, culture, democracy, as well as meeting the needs of citizens. In fact, effective public administration will ensure the confidence of citizens, which is an expression of the authority of the public service.

Public service is closely linked to many other institutions of public society. That is why the evaluation of the effectiveness of the public service is carried out through the lens of its social function, in the provision of appropriate legal bases, interaction with institutions that operate in the spiritual sphere of life of society, in the sphere of culture, is formed by mass communication, public opinion. Public service is also a complex legal institution, since it includes the rules of many areas of law: constitutional, administrative, financial, labor, criminal, housing, etc. [16]. Ensuring the prestige of the public service based on the principles of humanism and social justice presupposes the orientation of the professional activity of public servants to respect the constitutional rights and freedoms of Ukrainian citizens as the highest value of the state, ensure the quality of administrative services, improve the efficiency of public administration, create decent living conditions and promote the development of Ukraine.

5. Development of the country. The prestige of the public service promotes the formation of common values, areas of activity, public administration on the basis of a qualitatively new approach. Thus, economic, political, socio-cultural, information and technological features will be taken into account and aimed at supporting the country's sustainable development and economic growth by considering interaction 
not as an influence of the government on the private sector but as a cooperation.

Literature review. In today's transformational processes that are taking place in Ukrainian society, the institute of public service is becoming increasingly important. That is why various aspects of its functioning are analyzed in detail in their works by domestic experts, namely [1] studies it from the point of view of human dignity; [5, 7] analyze approaches to authority from the standpoint of professionalism. At the same time, the prestige of the public service was hardly explored. It was only fragmented in the context of the motivational crisis, the professional consciousness and the culture of public servants.

Some aspects related to the formation of a positive image of the government, the prestige of the public service, its authority, which, in turn, require increasing the level of public confidence in power, are revealed in the works $[18,9,24]$.

The issue of increasing the prestige of the public service is of great practical importance. It is impossible to attract highly professional employees to the public service without ensuring the high prestige of this type of activity. And without high-level professionals, in turn, one cannot claim effective public administration [6, 4, 13]. Thus, before setting the goal of raising the prestige of the public service, it is necessary to understand the system of values in modern Ukrainian society and to form mechanisms for the integration of these values into the public service. What is more, the question often arises not so much about raising prestige as about not reducing that prestige.

It is worth noting that the system of values of the Ukrainian society in relation to the public service consists of two components: material and intangible. And they, in turn, are divided into two levels, both causal and consequential [8]. Causal values include: wage levels, availability of social guarantees and benefits, including social insurance, retirement benefits and more. The hereditary, in turn, are formed on the basis of the primary and include: fluidity of the public service, age, etc. Intangible values are at least a fraction and consist of the level of respect, status, prestige and authority, the importance of this activity $[2,14]$.

It should be remembered that in addition to the causal values listed 
Cluster approach to increasing the prestige of public service

above, society also takes into account those that everyone knows and talks about but does not resolve. These are not statutory "preferences" that accompany the status of a public servant, in the implementation of which it is possible to talk about conflict of interest or corruption. They are based on the use of official position not in the interests of society: protectionism, mutual services, use of state property for personal purposes, as well as bribes, kickbacks and other illegal mechanisms of "transformation of power into money".

Thus, it is necessary to consider in more detail the main factors influencing the prestige of the public service. After evaluating all possible factors, we can distinguish those that most accurately and accurately reflect the results of the question under study.

Presenting main material. Public service modernization is one of the decisive priorities for public administration reform, for Ukraine to become a democratic state. Without modernization of the public service, it is impossible to overcome the problems existing in the public service system and in the activity of state bodies, and to ensure a significant increase in the standard of living of citizens. Only a consistent modernization of the public service in Ukraine, improvement of the existing public administration system will contribute to the creation of a professional, politically impartial, stable, highly efficient, reputable and prestigious public service capable of meeting the challenges of today and providing quality administrative services that meet European standards [24].

An effective prestigious public service is an element of the competitive advantage of the modern state in the global market. The study provides an assessment of the prestige and quality of the public service of Ukraine on the basis of such basic indicators (Table 1) as the salary of public servants (thousand $€$ ), the average salary of $€ /$ year, the number of citizens per official, population (thousand persons), profitability ratio, per capita income (thousand $€$ ), GDP per capita $(€)$, etc.

All indicators reflect the results of public administration and the development of public administration effectiveness, the higher the value of the first four and the Corruption Perceptions Index, the higher the level of efficiency and the value of which should go to the maximum. In terms of competitiveness indices and economic freedom, its value indicates 
freedom to a high level of development as it grows. The choice of the above indices is accompanied by a number of problems, among which the main one is that Ukraine is not yet part of a progressive international community that promotes policies to improve the economic and social well-being of the world's population. Hence the absence of Ukraine in most dimensions. Thus, with the support of the University of Oxford, the Institute of Governance and Public Service of Great Britain, the Open Society Fund, in 2017, the International Public Service Performance Index was developed and tested. The index includes an assessment of the main functions and attributes of the public service in the 31 st country, to which Ukraine, unfortunately, does not belong [20].

Another reason for choosing indicators is the compliance with their principle of public administration efficiency and the macroeconomic environment, as they reflect the opportunities and freedom to pursue activities [4, 15]. The indicators selected are also in line with the principle of accessibility and completeness, since under national law they are subject to mandatory publication in the media and evaluated by independent international experts (applies to selected indices). The most important reason for choosing these indicators is that they reflect the interests of the private and public sectors of the state. The vectors formed consist solely of factors that positively affect the prestige of the public service.

Table 1

\section{Indicators of ensuring the prestige of public service in different} countries of the world for 2017

\begin{tabular}{|l|c|c|c|c|c|c|c|}
\hline Country & $\begin{array}{c}\text { Sala- } \\
\text { ry }(€)\end{array}$ & $\begin{array}{c}\text { Aver- } \\
\text { age } \\
\text { salary } \\
€ / y\end{array}$ & $\begin{array}{c}\text { Num- } \\
\text { ber of } \\
\text { citizens } \\
\text { per one } \\
\text { the } \\
\text { official }\end{array}$ & $\begin{array}{c}\text { Popula- } \\
\text { tion } \\
\text { (thou- } \\
\text { sand } \\
\text { persons) }\end{array}$ & $\begin{array}{c}\text { The } \\
\text { rate } \\
\text { of } \\
\text { re- } \\
\text { turn }\end{array}$ & $\begin{array}{c}\text { Per } \\
\text { capita } \\
\text { inco- } \\
\text { me. } \\
\text { (thou- } \\
\text { sand } \\
€)\end{array}$ & $\begin{array}{c}\text { GDP } \\
\text { per } \\
\text { capita. } \\
\text { (thou- } \\
\text { sand } €)\end{array}$ \\
\hline Latvia & 27,49 & 8,36 & 26,00 & 1950,10 & 3,30 & 15,03 & 12,95 \\
\hline Romania & 18,75 & 5,99 & 29,00 & 19638,30 & 3,10 & 10,41 & 8,96 \\
\hline \hline
\end{tabular}


Cluster approach to increasing the prestige of public service

prolongaton tables 1

\begin{tabular}{|l|c|c|c|c|c|c|c|}
\hline Austria & 120,17 & 38,90 & 29,00 & 8772,90 & 3,10 & 44,87 & 39,39 \\
\hline Netherlands & 102,04 & 41,15 & 32,00 & 17081,50 & 2,50 & 45,76 & 40,27 \\
\hline Slovakia & 23,53 & 10,23 & 32,00 & 5435,30 & 2,30 & 17,21 & 14,71 \\
\hline $\begin{array}{l}\text { Czech } \\
\text { Republic }\end{array}$ & 27,25 & 12,59 & 38,00 & 10578,80 & 2,20 & 19,65 & \\
\hline Bulgaria & 16,32 & 4,62 & 39,00 & 7101,90 & 3,50 & 7,74 & 16,79 \\
\hline Hungary & 28,70 & 9,12 & 39,00 & 9797,60 & 2,90 & 13,31 & 12,94 \\
\hline Finland & 76,56 & 40,28 & 41,00 & 5503,90 & 1,90 & 43,63 & 38,33 \\
\hline Belgium & 86,06 & 43,39 & 42,00 & 7101,90 & 2,00 & 41,66 & 36,30 \\
\hline Malta & 21,15 & 18,74 & 42,00 & 440,40 & 1,10 & 26,88 & 22,70 \\
\hline Portugal & 49,32 & 18,35 & 47,00 & 10309,60 & 2,70 & 20,28 & 17,63 \\
\hline Greece & 68,46 & 25,67 & 47,00 & 10757,30 & 2,70 & 18,49 & 15,52 \\
\hline Ireland & 87,26 & 42,55 & 47,00 & 4774,80 & 2,10 & 41,90 & 58,84 \\
\hline Croatia & 24,49 & 12,49 & 48,00 & 4154,20 & 2,00 & 12,49 & 10,94 \\
\hline Italy & 167,26 & 31,68 & 50,00 & 6589,40 & 5,30 & 30,26 & 26,64 \\
\hline Estonia & 41,33 & 10,40 & 50,00 & 1315,60 & 4,00 & 18,97 & 16,53 \\
\hline Slovenia & 41,45 & 21,14 & 53,00 & 2065,90 & 2,00 & 21,85 & 19,70 \\
\hline $\begin{array}{l}\text { Great } \\
\text { Britain }\end{array}$ & 95,32 & 35,84 & 56,00 & 65808,60 & 2,70 & 38,25 & 33,10 \\
\hline Denmark & 91,77 & 49,71 & 56,00 & 5748,80 & 1,80 & 53,94 & 47,02 \\
\hline Cyprus & 47,32 & 26,93 & 65,00 & 854,80 & 1,80 & 23,69 & 20,81 \\
\hline Luxembourg & 75,32 & 51,66 & 67,00 & 590,70 & 1,50 & 104,08 & 88,13 \\
\hline Spain & 33,77 & 27,06 & 71,00 & 46529,00 & 1,20 & 27,55 & 23,62 \\
\hline Poland & 27,95 & 10,43 & 89,00 & 37973,00 & 2,70 & 13,45 & 11,52 \\
\hline Germany & 108,89 & 38,74 & 163,00 & 5748,80 & 2,80 & 42,20 & 37,11 \\
\hline Lithuania & 30,38 & 7,14 & 165,00 & 2847,90 & 4,30 & 16,01 & 13,94 \\
\hline Ukraine & 2,10 & 2,68 & 170,00 & 44030,00 & 1,40 & 2,42 & 2,15 \\
\hline France & 85,20 & 33,90 & 190,00 & 67024,50 & 2,50 & 38,09 & 33,21 \\
\hline Sweden & 79,11 & 28,72 & 224,80 & 9995,20 & 2,00 & 51,57 & 44,33 \\
\hline
\end{tabular}

Source: [20]

As well as highlighting and taking into account the main factors that influence the prestige of the public service, the following international indices have been taken into account in the research: corruption, competitiveness and economic freedom. On the basis of this, 
«Public Administration and Regional Development»

https://pard.mk.ua/index.php/journal

further research made it possible to form an integral indicator of the prestige of the public service.

Presented in Picture 2. the result of evaluating the prestige of the public service on the basis of coefficients makes it impossible to draw appropriate conclusions due to the inconsistency of the vector indicators. Therefore, there is a need for a more thorough analysis. For this purpose, clustering of public service prestige indicators was clustered.

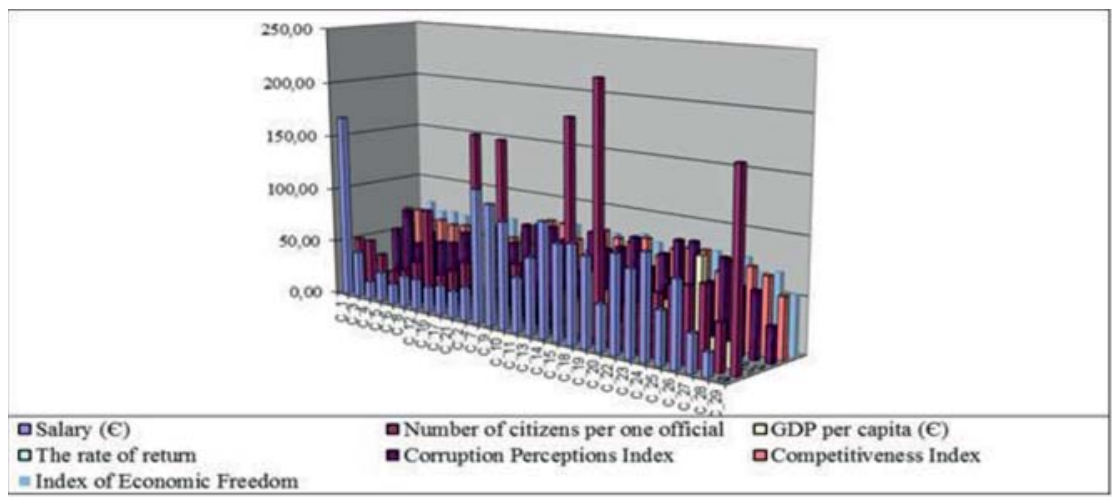

Picture 2. Assessment of the level of prestige of the public service by the selected indicators

Cluster analysis of public service prestige is a multidimensional statistical survey method that collects data on indicators that characterize the level of public service prestige in different countries of the world and organize them into relatively homogeneous, similar groups.

Therefore, the essence of cluster analysis lies in the classification of indicators that characterize the level of prestige of public service in different countries of the world through numerous computational procedures. As a result, clusters are formed. Unlike other methods, this kind of analysis makes it possible to classify a country's prestige not by one sign (indicator) but by several at a time. To this end, appropriate indicators are introduced to characterize a certain degree of closeness across all classification parameters. 
The purpose of cluster analysis of public service prestige in different countries of the world is to find available structures, which is expressed in the formation of clusters, is groups of countries in accordance with the level of prestige of public service. At the same time, its effect is to bring structure to the objects under study. This means that clustering techniques are necessary to identify the structure of the data, which is not easy to find with visual inspection or with the help of experts. Given the two groups of indicators, namely the indicators of the development of countries and the international indexes of their rating, this method is the most suitable for the study.

The main tasks of cluster analysis are: development of typology or classification of the studied objects; research and definition of acceptable conceptual schemes of grouping of objects; hypotheses based on the results of data studies; hypothesis testing or indeed the types (groups) that have been identified in a particular way are present in the available data [19].

Cluster analysis requires the following steps to be taken: a sample of objects for clustering public service prestige in different countries; identifying a set of features that will assess the prestige of public service in different countries of the world; assessment of the degree of similarity of countries; use of cluster analysis to create groups of similar countries; validation of cluster solution results.

Each of these steps plays a significant role in the practical implementation of the analysis. Cluster analysis is performed on the basis of comparable and unidirectional indicators. Therefore, the input matrix performance should be standardized first. One of the common ways for heterogeneous populations is to standardize indicators. The standardized input data obtained are presented in picture 3 .

It is established that the primary focus for cluster analysis is the use of a hierarchical mean linker method to identify the number of clusters to which country surveys will be allocated. This method is based on the average of all distances measured between the countries of the two clusters, with each pair comprising countries from different clusters [12]. 


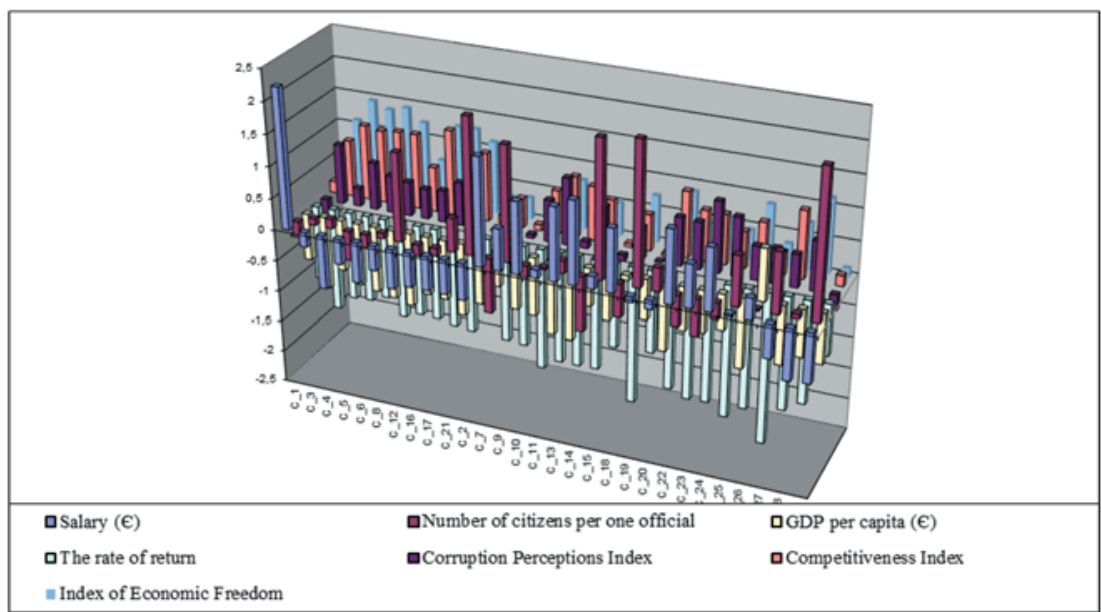

Picture 3. Normalized values of public service prestige indicators

Due to the fact that in the process of clustering by the English method of average communication uses data on all distances between pairs, not only the minimum or maximum distances, so this method is the most popular in the scientific environment, not the methods of single or complete communication.

According to the results of the cluster analysis, obtained using the hierarchical agglomerate method of average communication, used in the implementation of the iterative k-means method, that is, the input is the number of clusters into which the input population is broken, that is 4 clusters. The application of the k-means method first determines the center of the cluster and subsequently groups all the objects within the threshold given by the center. As a result of k-means clustering, the composition of the clusters obtained in Table 2.

Based on the research carried out using cluster analysis, cluster 1 has the lowest average value of variable I1 (wages), I3 (GDP per capita, I6 (Competitiveness Index). is within the values of other clusters, and accordingly the cluster is formed from countries with average rates of development, slightly lower than the average of others in this cluster of countries is corruption perceptions. is slightly less than in the relationship between government and business. 
The results of the classification of the objects of research by indicators of prestige of the public service

\begin{tabular}{|c|l|}
\hline CLUSTERS & \multicolumn{1}{|c|}{ OBJECTS OF CLASSIFICATION } \\
\hline 1 & $\begin{array}{l}\text { Estonia, Bulgaria, Latvia, Romania, Hungary, Poland, Slovakia, } \\
\text { Czech Republic, Croatia }\end{array}$ \\
\hline 2 & $\begin{array}{l}\text { Austria, United Kingdom, Portugal, Greece, Netherlands, Slovenia, } \\
\text { Belgium, Finland, Denmark, Cyprus, Spain, Malta }\end{array}$ \\
\hline 3 & Italy, Lithuania, Germany, France, Ireland, Sweden, Luxembourg \\
\hline 4 & Ukraine \\
\hline
\end{tabular}

Source: Systematized by the authors according to the results of cluster analysis.

Cluster 2 brings together the countries that have the highest values for variables I1, I5 and high enough for other indicators of the level of prestige of the public service. Thus, this cluster combined countries with higher wages and the lowest level of corruption. Also, this cluster is represented by the higher average value of the necessary-optimal number of public servants to secure the public administration system. The lower level of economic freedom indicates the dependence of enterprises, institutions and organizations on certain circumstances, namely the fundamental right of every person to manage his or her own work and property. In economically free societies, individuals are free to choose their jobs, produce goods, costs, and invest in whatever way they want. All these freedoms are supported and protected by the state. In economically free societies, too, the government allows labor, capital and goods to move freely and refrain from coercion and pressure on liberties, intervening only when it is necessary to preserve and function itself.

Cluster number three united countries with high values of corruption, competitiveness and economic freedom indices. At its core, the Competitiveness Index assesses countries' ability to provide a high ISSN 2616-6216. Publ. upr. reg. rozvit. 2020, 8: 496-514 
level of security for their citizens. First of all, it depends on the efficiency of the use of available resources in the country. At the same time, constant improvement of the level of labor productivity and quality of goods and services is required. The methodology for applying the Competitiveness Index focuses on emerging competitiveness factors associated with the rapid spread of digital technologies that have not previously been a priority in government policy decisions. It's about generating ideas, entrepreneurial culture, innovation, openness and adaptability.

Cluster 4 - a country (Ukraine) that is a member of the cluster shows, by virtue of all values, the average values (I1, I3 - I7) with the highest value of $\mathrm{I} 2$, ie the highest number of citizens per 1 official.

The analysis of the studies on the basis of which the Corruption Perceptions Index has been calculated indicates that there is a certain decrease in the level of corruption in business-government relations. In Ukraine, this could have been facilitated by the automatic reimbursement of the Value Added Tax, the functioning of the Institute of Business Ombudsman and ProZorro electronic systems. Sales. Restoring confidence in the justice system remains a key challenge, according to the business. The increase in the Corruption Perceptions Index of Ukraine in recent years has been hampered by widespread cases of pressure and attacks on activists and journalists working in the field of combating corruption. Ukraine's performance is still worse than that of its neighbors: Poland, Hungary and others.

Conclusions. The results of the analysis of reliability and adequacy made it possible to conclude that there is a high level of reliability. The cluster analysis shows that most countries belong to cluster №2, cluster with a sufficient level of prestige of the public service, which adequately reflects the state and trends of public administration. Also in the second cluster are the European Union Founders, namely Belgium and the Netherlands. The study provides the following recommendations for maintaining the prestige of the public service by enhancing the level of economic freedom.

Cluster №3 countries, most of the EU Founding Countries (Germany, Italy, France and Luxembourg), are accompanied by a high level of prestige in the public service based on high levels of economic 508 Isue DOI: 10.34132/pard 
Cluster approach to increasing the prestige of public service

and political stability. These countries will be characterized by a strategy of maintaining an appropriate level of public service prestige through the lens of consistently high growth rates.

Thus, analyzing cluster №2 and №3, we can conclude that the prestige of the public service of the countries that joined these clusters was formed on the classical postulates of the political ideology of the European Union with respect for the principles of democracy, independence and freedom.

The second largest cluster, №1, includes former socialist countries. During the economic transformation, these countries exhibit sufficiently high rates of economic growth and average public service prestige. Based on the lowest wage rates of public servants among the countries surveyed, it can be concluded, however, that the priorities of the public servants of these countries are economic growth and well-being of citizens.

Cluster №4, which is a cluster with a low level of prestige in the public service, has only one country - Ukraine. Describing the results of the analysis, the following characteristics can be formulated, namely, the level of prestige of the public service is determined, first of all, by high salaries of public servants (emphasis is not placed on employees of the lowest ranks who receive low salaries) and their high numbers. However, the clustering results indicate that the distance of most indicators such as, GDP per capita, profitability ratio, corruption perception index, competitiveness index, economic freedom index is approaching cluster №1. This demonstrates the positive dynamics and closely related content of the strategy of development of the state administration and the state to the neighboring countries by territorial and historical affiliation.

Public service is a link between the state and society and represents the sphere of professional activity in the protection of the rights and interests of citizens, the form of manifestation of public relations and relations, the way and means of bringing the constitutional ideal of the state closer to objective reality, not only political and legal, but also the ethical system of power relations.

Updating the prestige of the public service is caused not only by the negative tendencies of its present state, but also by the prerequisites caused by moral and ethical principles (patriotism, expectation, dynasty, 
etc.). Studying the value and valuation nature of prestige allows us to predict the dynamics of change and transformation of social values; the decline of the prestige of socially important spheres of human activity.

The prestige of the public service is of paramount functional importance, since it is the public servants who are the real leaders of the ideas of statehood in practice. The prestige of the public service depends to a large extent not only on its availability of highly qualified personnel, but also on the efficiency, but also on the trust, respect of the population, how the laws and regulations of public authorities will be perceived in public opinion. The prestige of the public service is a key indicator of the state's effectiveness and strength in the international environment. It also directly affects the state's ability to provide services to the population, promote competition and growth.

The most important solution to the low level of prestige of the public service is to critically ensure the full use of the national talent pool. This implies job creation based on equal opportunities by gender, age, ethnic origin and other comparable criteria.

The effectiveness of the reform of the Ukrainian public service must be accompanied by the creation of a professional, politically impartial, stable, highly efficient, authoritative and prestigious public service capable of meeting the challenges of today and providing quality administrative services that meet European standards.

\section{Received: 26.03 .20}


Cluster approach to increasing the prestige of public service

\section{КЛАСТЕРНИЙ ПІДХІ ДО ПІДВИЩЕННЯ ПРЕСТИЖУ ПУБЛІчнОї СЛУЖБИ}

Назар Подольчак, д-р. екон. наук, професор, Національний університет «Львівська політехніка», м. Львів, Україна

Вероніка Карковська, канд. екон., наук, доцент, Національний університет «Львівська політехніка», м.Львів, Україна

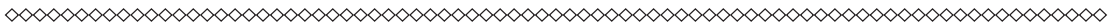

Підвищення престижу публічної служби є необхідною умовою успішної європейської інтеграиії та доброго та ефективного державного управління, яке відповідає вимогам сучасності та європейським стандартам та принципам належного управління. Метою статті є вивчення престижу публічної служби за допомогою кластерного аналізу. В статті розглянуто напрями підвищення престижу публічної служби та виокремлено основні переваги. Дослідження здійснено на основі аналізу показників, щяо безпосередньо впливають на формування престижу публічної служби Украӥни та провідних країн. Також для врахування престижу обрано міжнародні індекси, які є результуючими щодо ефективності державного управління та макроекономічного середовища, оскільки відображають можливості та свободу реалізащії діяльності. За допомогою кластерного аналізу здійснено класифікацію показників, які характеризують рівень престижності державної служби в різних краӥнах світу. В результаті чого розглянуто утворення кластерів престижності державної служби в різних країнах світу та представлено практичні рекомендації щодо ї̈ підвищення. Встановлено, щуо престиж публічної служби має першорядне функиіональне значення, оскільки саме державні службовці є реальними лідерами ідей публічності на практиці. В статті зроблено висновки, щзо престижність публічної служби значною мірою залежить не лише від iï наявності висококваліфікованого персоналу, але й від ефективності, а й від довіри, поваги населення, від того, як сприйматимуться закони та положення органів публічної влади в громадська ISSN 2616-6216. Publ. upr. reg. rozvit. 2020, 8: 496-514 
«Public Administration and Regional Development»

https://pard.mk.ua/index.php/journal

думка. Престиж публічної служби є ключовим показником ефективності та сили держави в міжнародному середовищі. Це також безпосередньо впливає на здатність держави надавати послуги населенню, сприяти конкуренції та зростанню.

Ключові слова: престиж публічної служби, кластерний аналіз, показники забезпечення престижності публічної служби, кластеризація країн, рівень престижності публічної служби.

\section{References}

1. Barkov, V. (1999). Human dignity and social prestige Philos. opinion. Nos. 1 - 2, pp. 252 - 274 [in Ukrainian].

2. Bityak, Yu. P. (2006). Public Service in Ukraine: Problems of Formation, Development and Functioning. Yaroslav the Wise, 419, 380-419 [in Ukrainian].

3. Dendel, S. Y., \& Mashley, G. B. (2018). Basic approaches to public administration. Public Administration and Administration: Competitive Challenges of the Present: Proceedings of the All-Ukrainian Scientific and Practical Internet Conference. Lviv: Liga-Press LLC [in English].

4. Dikan, O. V., Dikan, V. V., \& Glushenko, T. M. (2018). Planning and career development of public servants. X .: Harri Nadu Publishing House, 173177 [in English].

5. Goncharov V. V. (1996) In search of management excellence: A guide for senior management personnel: in 2 volumes M.: MNIIPU, Volume 1: Experience of the best industrial firms of the USA, Japan and the countries of Western Europe, 752 [in Ukrainian].

6. Goncharuk, N. T. (2018). Development of the public service of Ukraine in terms of its reform and modernization. Approved by the Academic Council of the Dnipropetrovsk Regional Institute of Public Administration of the National Academy of Public Administration under the President of Ukraine. Minutes No. 09/220 of 06 December 2018, 9 [in Ukrainian].

7. Gorzov, A., \& Longy, O. (2017). Disciplinary responsibility of public servants. Scientific Journal of the National Academy of Public Prosecutor of Ukraine, (1), 13 [in Ukrainian].

8. Karkovska, V. Y. (2018). Knowledge management: actualization of 512 Isue DOI: 10.34132/pard 
Cluster approach to increasing the prestige of public service

public administration. Public Administration and Administration in the Process of Economic Reforms: Proceedings of the Reports of the Second All-Ukrainian Scientific and Practical Internet Conference, October 17, 2018 - Kherson: State Higher Education Institution "KhSAU”, 221 [in Ukrainian].

9. Kushnirenko, I. Y. (2018). State human resources policy in Ukraine: problems and development prospects. Bulletin of the International Humanities University, 15, 97-100 [in Ukrainian].

10. Kvasha, O. S. (2019). Formation of image of bodies of the state fiscal service of Ukraine [in Ukrainian].

11. Larina, N. I., \& Makaev, A. I. (2006). Clustering as a way to increase the international competitiveness of countries and regions. All-Russian Economic Journal of ECO, (10 (388)) [in Russian].

12. Malhotra, N. K. (2002). Marketing research. Practical Guide. M .: Williams [in English].

13. Moroz, S. A. (2017). Accreditation of educational programs as a method of public administration of higher education quality [in Ukrainian].

14. Podolchak, N.Y., Prokopyshyn-Rashkevych, L.M., \& Karkovska, V.Y. (2019). The influence of coaching on the development of manager's leadership skills. Naukovyi Visnyk Natsionalnoho Hirnychoho Universytetu, 4, 107-113 [in Ukrainian].

15. Scotch, A. W. (2007). Clustering efficiency of the regional economy. Economic Strategies, 9 (5-6), 160-167 [in English].

16. Strielkowski, W., Gryshova, I., Kalyugina, S. ( 2017) Modern technologies in public administration management: A comparison of Estonia, India and United Kingdom. Administratie si Management Public, 28, 174-185 [in Ukrainian].

17. Ukraine, Z. (2019). About the public service. The Verkhovna Rada of Ukraine, 52, 490 [in Ukrainian].

18. Zhivko, Z. B., Kurlyak, M. D., Pushak, E. J., Revak, I. O., Tomanevich, L. M., \& Franchuk, V. I. (2017). Public administration and economic security in the context of European integration: a monograph [in Ukrainian].

19. Zinchenko, O. A., \& Zinchenko, D. S. (2019). Formation of investment attractiveness of the country in the aspect of economic clusters as a factor of intensification of cross-border partnership. Bulletin of the Kiev National University of Technology and Design. Series Economic Sciences [in Ukrainian]. 
«Public Administration and Regional Development» https://pard.mk.ua/index.php/journal

20. The Global Competitiveness Report 2018. Retrieved from http:// reports.weforum.org/global-competitiveness-report-2018/?doing_wp_cron=15 69833103.1690549850463867187500 [in English].

21. Soroka S. (2018). Public Service Reform: Do Salaries Really Decide? Retrieved from https://rpr.org.ua/news/reforma-derzhsluzhby-chy-spravdizarplaty-vyrishuyut-vse/ [in Ukrainian].

22. Presidential Decree (2015). On the Ukraine 2020 Sustainable Development Strategy, 5, 6 [in Ukrainian].

23. International public service effectiveness (incise) index (2019). Blavatnik School of Government, University of Oxford, Radcliffe Observatory Quarter, United Kingdom. Retrieved from https://www.bsg.ox.ac.uk/about/ partnerships/international-public-service-effectiveness-index-2019 [in English].

24. Prodius, L. (2017). Modern requirements for the quality management of the public service taken into account of domestic and foreign experience [in English].

\section{Information about the Authors:}

Podolchak Nazar: Lviv Polytechnic National University, 12 Bandera str., Lviv, 79013, Ukraine.

ORCID. ORG./0000-0002-0284-9601

\section{E-mail: nazar_podolchak@yahoo.com}

Karkovska Veronika: Lviv Polytechnic National University, 12 Bandera str., Lviv, 79013, Ukraine.

\section{ORCID. ORG./0000-0003-0178-4137}

\section{E-mail: veronika.y.karkovska@Ipnu.ua}

